\title{
Influence of Transformational Leadership Perception in Employee Performance: Perception of Learning Organizations and Innovations as Mediator (Study in CV. Amigo Mangesti Utomo)
}

Ogy Septiadi; Heru Kristanto

Universitas Kristen Duta Wacana, Indonesia

http://dx.doi.org/10.18415/ijmmu.v6i5.1151

\begin{abstract}
The purpose of this research was to determine the effect of transformational leadership on organizational performance :mediation of organizational learning and innovation ( Study in CV. Amigo Mangesti Utomo ). The research approach used is a type of empirical research, with data collection methods used by survey techniques, using a Likert scale in the survey with a rating interval between scores of 1-5, where score 1 indicates a very dissatisfied perception while score 5 indicates a very satisfied perception. The sample in this research is permanent employees (who work more than one year) in CV. Amigo Mangesti Utomo. The analysis method used to determine the relationship between variables is path analysis using the structural equation model (SEM) method and the AMOS program. The results of testing the hypothesis are as follows: 1. The variable of transformational leadership perception has a positive and significant effect on innovation, 2. The variable of transformational leadership perception has a positive and significant effect on innovation, 3 . The variable of organizational learning perception shows results that have no significant effect on innovation, 4. Variable perception of organizational learning has a positive and significant effect on employee performance, 5. Innovation variable has a positive and significant effect on employee performance.
\end{abstract}

Keywords: Transformational Leadership Perception; Employee Performance; Organizational Learning Perception; Innovation

\section{Introduction}

CV Amigo Mangesti Utomo is a fashion retail company with 9 branches or stores spread across Central Java and Yogyakarta. This company really upholds organizational culture which is still traditional or tends towards Javanese culture and always moves based on existing values. Closeness between employees ranging from employees with managerial positions up to salesperson level employees is very harmonious because there is a traditional organizational culture (tends towards Javanese culture), which always maintains friendship and family ties. 
Although closeness is always maintained, it does not make a good working relationship between leaders and subordinates. Leaders who are unable to provide direction, good examples, motivation and inspire make employee performance less than optimal, so employee performance in the form of sales targets, service quality and work attendance are less than optimal. As a result of leaders who are less inspiring and assign tasks and many require maximum work and quickly finished without wanting to know the process that occurs makes employees feel less valued. Without the intervention in the form of learning from the leader in assigning tasks or work makes employees feel the lack of attention from superiors so that the lack of employee interest in maximizing the ideas they have so the lack of innovation that appears.

Bass and Avolio (1999) argue that transformational leadership as a leadership style that increases awareness of collective interest among members of an organization and helps them achieve their collective goals. Whereas, transactional leadership focuses on promoting the individual interests of leaders and their followers and achieving satisfaction of contractual obligations on the part of both by setting goals and monitoring and controlling results. Bass (1999) revealed that transactional and transformational behaviors are used by leaders to different degrees. Transformational leadership is the focus of this investigation. Transformational leadership theory emphasizes emotions, values, and the importance of leadership which is oriented to fostering employee creativity. Employees are valuable resources in the company, transformational leaders are responsible for the development of professional resources that he promotes (Bass, 1999; Bass and Avolio, 2000; García Morales et al., 2008a, b).

Creating emotional connections with followers and inspiring higher values is an effort of the transformational leadership style. Such leadership style exudes the importance of having a shared mission and instills a sense of purpose, direction, and meaning in the work of the followers (Bass, 1999). Transformational leadership becomes the driver and transmitter of innovative culture and knowledgeoriented dissemination to find the best organizational performance. Examples of transformational leadership that are committed to organizational goals and their internalization within followers aim to encourage commitment to results on the part of organizational members (Bass, 1999; Bass and Avolio, 2000).

A leader with a transformational leadership style is a leader who has charisma, provides inspiration and promotes intellectual stimulation (Bass, 1999; Bass and Avolio, 2000; Conger, 1999). Charisma inspires pride, confidence and respect that leaders work to encourage their employees to own themselves, their leaders, and their organizations. Leaders with transformational leadership styles provide inspiration by motivating their followers, mostly through communication of high expectations. Such leaders also promote intellectual stimulation by promoting employee intelligence, knowledge, and learning so that employees can be innovative in their approaches to problem solving and solutions.

Many studies analyze the effects of transformational leadership on organizational performance through medium constructions such as culture (for example, Ogbonna and Harris, 2000), entrepreneurship (for example, García Morales et al., 2006), knowledge management (for example, Gowen et al., 2009), suitability in top management teams (for example, Colbert et al., 2008), flexibility (for example, Rodriguez Ponce, 2007), human resources that improve human resource management (Zhu et al., 2005), competitive strategies (eg, Menguc et al., 2007), and absorption capacity (for example, García Morales et al., 2008a, b). However, the understanding of the process by which leaders exert influence is still limited and highly speculative (Bass, 1999; Conger, 1999). This investigation seeks to analyze empirically whether transformational leadership influences organizational performance through the influence between organizational learning and innovation.

DiBella et al., (1996) suggested that organizational learning is the ability "in an organization to maintain or improve performance based on experience. This activity involves the acquisition of 
knowledge (development or creation of skills, insights, and relationships), sharing of knowledge (dissemination to others about what has been obtained by some), and utilization of knowledge (integration of learning so that it is assimilated and widely available and can be generalized to situations new). Organizational learning is the process by which organizations increase the knowledge created by individuals in an organized way and transform this knowledge into part of an organization's knowledge system. This process occurs in community interactions where organizations create knowledge, which develops in a constant dynamic between tacit and explicit (Nonaka and Takeuchi, 1995). Organizational learning allows the development of new skills and knowledge and improvement of organizational capabilities.

Empirical studies support the relationship between organizational learning and innovation (Bueno et al., 2010; Cohen and Levinthal, 1990; Glynn, 1996; Hurley and Hult, 1998; Ireland et al., 2001; Mezias and Glynn, 1993). Various types of learning and innovation are also related. For example, generative learning is the most advanced form of organizational learning and occurs when organizations are willing to question long-held assumptions about their mission, customers, abilities, and strategies and to produce changes in practices, strategies, and values.

The literature also suggests the importance of organizational learning and innovation for corporate survival and effective performance. Organizational learning is a major component in every effort to improve organizational performance and strengthen competitive advantage. The development of new knowledge, which comes from organizational learning, reduces the likelihood that a company's competencies will become obsolete, enabling competencies to remain dynamic and thereby supporting performance improvement. Organizational learning usually has a positive connotation, because this form of learning is related to performance improvement (Argyris and Schön, 1996; Fiol and Lyles, 1985; Inkpen and Crossan, 1995; Ireland et al., 2001; Senge, 1990). Various authors also point out that innovation is very important to improve performance and innovations that come into play to improve organizational performance (Argyris and Schön, 1996; Damanpour, 1991; Fiol and Lyles, 1985; Hurley and Hult, 1998; Senge, 1990; Zaltman et al., 1973).

From this description, a study was proposed with the aim of analyzing the effect of transformational leadership perceptions on employee performance: perceptions of organizational learning and innovation as mediators (Study at CV. Amigo Mangesti Utomo).

\section{Literature Review}

\subsection{Theory}

\subsubsection{Perception}

Greenberg and Baron (2000) state that perception is a process experienced by someone in selecting, organizing and interpreting information. A similar understanding was expressed by Kotler et al. (2013) which explains that perception is where we choose, organize, and translate information input to create a meaningful picture of the world

\subsubsection{Transformational Leadership}

Transformational leadership is a model of leadership to improve human resources with and the relationship between leaders' effects on subordinates can be measured, with indicators of trust, admiration, loyalty, and respect for leaders, trying to motivate followers to do something more and do it beyond their own expectations ( Bass \& Avolio, 1994). 
Bass and Avolio (1994) found that transformational leadership has four behavioral components, namely: idealized influence, inspirational motivation, intellectual stimulation, and individualized consideration. The following is a brief explanation of the components; (a) The influence of Idealism is the behavior of a transformational leader who has strong self-confidence. He is always present in difficult times, he also upholds the values that he upholds. High commitment always accompanies the leader's steps. He brings pride to his followers. He is a clear visionary, and his steps always have a definite goal. Above all, he is a diligent person. (b) Inspirational motivation is the behavior of transformational leaders, in which they reflect, think, and always identify the needs of their employees. He tried his best to recognize the ability of employees. Awakening the enthusiasm of learning for its employees, not only that, it also provides the broadest learning opportunities. He instead became their coach, and he always listened to his employees attentively. He realized that he could not be alone, so he was a person who dared to delegate his authority. For him, empowered employees are the key to the success of a work. (c) Intellectual stimulation (intellectual stimulation) is the effort of transformational leaders in inspiring their followers to achieve unimaginable possibilities. Challenged by employees reaching high standards. He invites employees to view threats and problems as opportunities for learning and achievement. Therefore, he created the culture to dare to be wrong, because mistakes are the beginning of the learning experience of all things. For him, the word is his main weapon. With words he also arouse employee enthusiasm. He uses symbols and metaphors to motivate them. This leader is always enthusiastic when he talks, he is an optimist. Invited employees to find deep meaning in work. So that employees want to follow him voluntarily, he places himself as an example to his followers. (d) Individualized consideration is a transformational leader weapon in inviting employees to see a new perspective. Imagination, combined with intuition but guided by the logic utilized by this leader in inviting employees to be creative. He is anxious about the status quo, so he asks why organizations must remain in the status quo. He invites employees to dare to challenge the money tradition, and he also invites employees to ask questions about old assumptions. He realizes that often certain beliefs have impeded thinking patterns, therefore, he invites his employees to question, research, study and if necessary replace that trust.

\subsubsection{Organizational Learning}

Learning Organization is defined by Watkins and Marsick (1996: 32) as something where work learning is integrated in a sustainable and systematic way to support continuous improvement at the individual level of groups and organizations. In other words, learning takes place in individuals, teams and organizations and even the communities in which the organization interacts. LO is also used to improve an organization's problem solving abilities and about behavior change in ways that lead to improved performance at the individual, team and organizational level.

According to Watkins and Marsick (1996) the characteristics or seventh necessity for LO complementary actions are; creating sustainable learning opportunities, promoting inquiry and dialogue, encouraging team collaboration and learning, building systems to capture and share learning, empowering communities towards a collective vision, connecting organizations with their environment and providing strategic leadership for learning

\subsubsection{Innovation}

Innovation is introducing new ideas, new goods, new services and new ways that are more useful. Amabile et al. (1996) defines innovation that has to do with creativity is Innovation or innovation comes from the word to innovate which means to make changes or introduce something new. Innovation is sometimes also interpreted as an invention, but the meaning is different from the discovery in the sense of discovery or invention. 
Innovation can be positive or negative. Positive innovation is defined as the process of making changes to something that has been established by introducing something new that adds value to customers. Negative innovations cause customers to be reluctant to use the product because it has no added value, damaging the customer's lost sense and trust.

There are 5 types of innovation according to experts, namely: (a) Product innovation; which involves the introduction of new goods, new services that are substantially increased. It involves enhancing the functional characteristics too, the technician's ability, it's easy to use it. For example: mobile phones, computers, motorized vehicles, etc.; (b) Process innovation; involves the implementation of improving the quality of new products or shipping goods; (c) Marketing innovation; developing methods of finding new market shares by improving the quality of design, packaging, promotion; (d) Organizational innovation; new organizational creations, business practices, ways of running an organization or organizational behavior; (e) Business model innovation; change the way you do business based on your values. Innovation is determined by market and business characteristics. Innovation that follows the conditions allows the market to run as usual. Separate innovation, can change the market or product for example the discovery of cheap goods, cheap airline tickets. Incrementation innovation (enhancer) arises because of the evolution in thinking innovation, the use of technology that increases the chances of success and reduces imperfect products. Radical innovation, changing the manual process into a technology-based process as a whole.

\subsubsection{Employee Performance}

Performance has become a very interesting popular word in public management talks. The concept of performance can basically be seen from two aspects, namely employee performance (perindividual) and organizational performance. Performance is a picture of the level of achievement of the implementation of tasks in an organization, in an effort to realize the goals, objectives, mission, and vision of the organization (Bastian, 2001: 329).

Bernardin and Russel (2010), provide the following understanding or performance: "performance is defined as the record of outcomes produced on a specified job function or activity during time period". Achievement or performance is a record of the results obtained from certain job functions or activities during a certain period of time.

Mathis and Jackson (2009: 378) suggested that performance can be indicated or measured through; (a) The quality of work with items that is quality; careful maintenance of office equipment; thorough completing work; speed of responding to complaints; and the speed at which tasks are completed (b) The quantity of work with items is the number of tasks completed; recording and reporting implementation; maintenance of cleanliness of the work space; preparation of work plans before carrying out tasks; the main work can be completed in accordance with the quantity standard set by the organization. (c) Timeliness of work with items ie overtime willingness to pursue work targets; work completed on time; attend regular meetings; come to work on time; results of work with a predetermined time allocation; and effectively utilizing time. (d) Attendance with items ie time discipline and attendance at work.

Based on the definition of performance above explains the picture of the level of achievement of the performance of tasks performed by all employees in an organization or government agency. Improving performance in an organization or government agency is the goal or target to be achieved by organizations and government agencies in maximizing an activity. 


\subsection{Research Hypothesis}

\subsubsection{The Influence of Perceptions of Transformational Leadership on Perceptions of Organizational Learning and Innovation}

Earlier research confirmed the relationship between leadership and organizational learning (McGill et al., 1992; Senge, 1990; Senge et al., 1994; Tushman \& Nadler, 1986). Transformational leadership builds teams and gives them direction, energy, and support for the process of organizational change and learning (Bass, 1999; McDonough, 2000). This style of leadership enables organizations to learn through experimentation, exploration, communication and dialogue (Lei et al., 1999; Menguc et al., 2007; Senge et al., 1994; Slater \& Narver, 1995; Tushman \& Nadler, 1986 ).

Specifically, transformational leadership encourages organizational learning by providing intellectual stimulation and providing inspirational motivation and confidence among organizational members (Coad \& Berry, 1998). Leaders with transformational leadership styles will be a catalyst, mentor, facilitator and trainer in organizational learning. He encourages shared mental models in technological organizations that support continuous learning and facilitate learning of technology and the use of new technologies (Senge et al., 1994).

Hypothesis 1. Perceptions of transformational leadership are positively and significantly related to perceptions of organizational learning.

Previous literature highlights leadership style as a very important influence on organizational innovation (Kanter, 1983; McDonough, 2000; Van de Ven, 1986). Today's broad consensus companies that collaborative and participatory (transformational) leadership styles are more likely to encourage innovation within organizations (Kanter, 1983) than transactional leadership styles (Manz et al., 1989). Managers' perceptions of their role in their organization greatly influence the ability to promote such leadership in an organization.

Transformational leaders have charisma, provide inspiration, and promote intellectual stimulation. These characteristics encourage organizational communication and learning processes that enable organizations to become more innovative (Bass, Bass \& Avolio, 2000; Conger, 1999). Transformational leadership thus influences innovation indirectly through communication processes (García-Morales, 2004; Tushman \& Nadler, 1986) and processes (Nonaka \& Takeuchi, 1995; Senge et al., 1994). Furthermore, transformational leadership has an indirect effect on innovation based on the presence of both strategic factors (communication and organizational learning) and the interrelation between them (Lei et al., 1999; Schein, 1993; Senge, 1990).

Hypothesis 2. Perception of transformational leadership is positively and significantly related to innovation.

\subsubsection{Influence of perception of organizational learning on innovation}

In recent decades, various literature on organizational innovation has received important contributions from learning work. Much of this research looks at the positive relationship between organizational learning and organizational innovation (for example, Calantone et al., 2002; Tushman and Nadler, 1986). Various types of organizational learning (adaptive / generative) and innovation (incremental / radical) have a close and positive relationship (Forrester, 2000). The deeper innovation is achieved, the greater the level of learning needed. 
Therefore, the more innovative the product, service or method, the greater the level of critical capacity, skills and new and relevant knowledge needed (Senge et al., 1994). The process of creating organizational knowledge, which draws new knowledge from existing (organizational learning), is an innovative foundation of activity.

Hypothesis 3. Perception of organizational learning is positively and significantly related to innovation.

\subsubsection{Influence of Perception of Organizational Learning and Innovation on Employee Performance}

Various literatures emphasize the importance of organizational learning for corporate survival and effective performance (Argyris \& Schön, 1996; Fiol \& Lyles, 1985; Inkpen \& Crossan, 1995; Senge, 1990). However, empirical analysis of this relationship has been limited, due to various difficulties, such as ambiguity or time delay between the two (today's learning will affect tomorrow's performance) and the possibility that exogenous factors disguise learning outcomes. Research must analyze the effect of organizational learning on performance in technology companies empirically, but little knowledge is available about the mechanisms that transform organizational learning into performance (Inkpen \& Crossan, 1995; Snyder \& Cummings, 1998).

Organizations that encourage enthusiasm for learning (to some extent) direct performance to achieve future performance, because direct performance is due to organizational learning taken from yesterday, while future performance will be a product of the current learning process (Guns, 1996; Senge, 1990).

Hypothesis 4. Perception of organizational learning is positively and significantly related to employee performance.

\subsubsection{Effect of Innovation on Employee Performance}

Various theories reveal that innovation is very important for better performance. According to marketing theory, organizations that concentrate on the speed of innovation get a greater market share, which results in high revenues and high profitability. The strategic theory is that organizations that adopt the first innovation are able to create an isolation mechanism. Because knowledge of innovation is not available to competitors, this mechanism protects profit margins, enabling organizations to get important benefits. Likewise, resource theory and capability maintain that the capabilities, resources and technology needed to adopt innovation make external imitation more difficult and allow companies to maintain their competitive advantage and obtain greater performance (Irwin et al., 1998; Lengnick- Hall, 1992; Lieberman \& Montgomery, 1988).

Thus, there is a positive relationship between innovation and performance (Zahra et al., 2000; Zaltman et al., 1973), or between different aspects of innovation (for example, design innovation or speed, flexibility) and performance (Calantone et al. , 2002; Capron, 1999; Danneels \& Kleinschmidt, 2001; Gopalakrishnan, 2000; Hall \& Bagchi-Sen, 2000). The innovation literature also includes various empirical studies that support this relationship, as well as works that use econometric methods to show relationships empirically (Lööf \& Heshmati, 2002).

Hypothesis 5. Innovation is positively and significantly related to employee performance. 


\subsection{Hypothesis Model}

The model used in this study is as shown in the following figure:

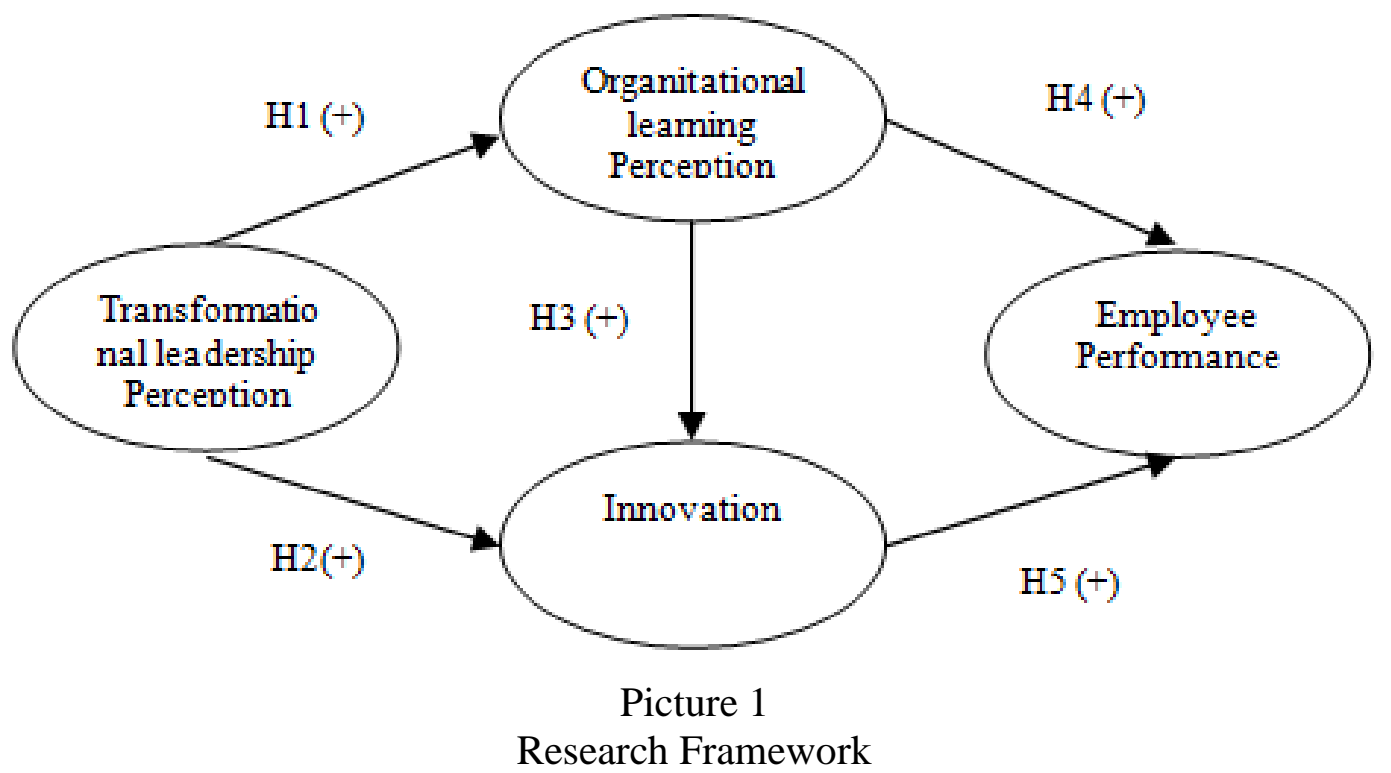

\section{Research Methods}

\subsection{Population and Sample}

The population in this study were employees at CV. Amigo Mangesti Utomo, not including 1 (one) Director and 1 (one) Deputy Director as top management.

The sample of this study was a portion of the employee population, namely permanent employees (who worked for more than one year) CV. Amigo Mangesti Utomo.

\subsection{Data Collection}

This study uses two types of data, namely (1) primary data, which is data that can be collected and by an organization or individual directly from the object of research (Sugiyono, 2016). In this study primary data were obtained through a questionnaire, which is a method of collecting data by making a list of written questions to the respondents surveyed. The questionnaire consists of five parts, the first part contains questions related to the profile of respondents, the second to the fifth section contains questions about the variable components of the Influence of Transformational Leadership Perception on Employee Performance: Perception of Organizational Learning and Innovation as a Mediator. And (2) secondary data is data that is not obtained directly from the object of research, the data has been collected and processed by other parties. Secondary data used in this study are books, research journals, lecture notes and other references related to the problem under study. This was done in order to obtain scientific conclusions from the problem under study (Sugiyono, 2016).

\subsection{Variable Measurement}

Measurement of each of these variables using a five-point Likert scale or often called the ordinal scale because the measurement uses the ordinal scale, Imam Ghozali, (2002: 41). Rating intervals 
between scores $1-5$, where score 1 shows perception is very dissatisfied while score 5 shows perception is very satisfied.

In this research, the exogenous (independent variable) variable is Transformational Leadership Perception, while the endogenous variable (dependent variable) is the Organizational Learning Perception, Innovation and Employee Performance. The variable of perception of transformational leadership with X1, perception of organizational learning Y1, innovation Y2, while employee performance with Y3. Will be explained as follows;

\subsubsection{Independent Variable}

\subsubsection{Transformational Leadership Perceptions}

Transformational Leadership Perception is a model of leadership to increase human resources with and the relationship between leaders' effects on subordinates can be measured, with indicators of trust, admiration, loyalty, and respect for leaders, trying to motivate followers to do something more and do it beyond their own expectations (Bass \& Avolio, 1994).

This variable is measured at the individual level with the indicators in this paper are as follows; (a) Idealization of Influence: Transformational leaders behave in ways that allow them to be seen as ideal models for followers. (b) Inspirational Motivation: Transformational leaders behave in ways that can motivate and inspire those around them by giving meaning and challenge to the work done by their followers. (c) Individual Consideration: Transformational leaders pay special attention to the needs of each follower in order to achieve achievement and development by acting as well as trainers and mentors. (d) Intellectual Stimulation: Transformational leaders stimulate followers' efforts to be creative and innovative by questioning basic assumptions (assumptions), mapping problems, and updating old approaches.

\subsubsection{Dependent Variable}

\subsubsection{Perception of Organizational Learning}

Perception of Organizational Learning as something where work learning is integrated in a sustainable and systematic way to support continuous improvement at the individual level of groups and organizations (Watkins \& Marsick, 1996). This variable is measured at the individual level with the indicators in this paper are as follows; creating sustainable learning opportunities, promoting inquiry and dialogue, encouraging team collaboration and learning, building systems to capture and share learning, empowering communities towards a collective vision, connecting organizations with their environment and providing strategic leadership for learning.

\subsubsection{Innovation}

Defining innovation that has to do with creativity is Innovation or innovation derived from the word to innovate which means to make changes or introduce something new (Amabile et al, 1996).

The indicators in this paper are as follows; (a) Product and Service Innovation (Technically) is the creation and transformation of a product into a new product to increase liking for the product. (b) Process Innovation (Administration) is a process update or method commonly used to produce, usually the use of new technology. 


\subsubsection{Employee Performance}

Employee Performance is a record of the results obtained from certain job functions or activities during a certain period of time (Bernardin and Russel, 2010).

According to Mathis and Jackson (2009: 378), in Innovation there are four components. The indicators in this paper are as follows; (a) The quality of work or the quality of work results which assesses whether or not the work of employees. (b) Work quantity is the amount of work the leader gives to the employee / the quantity of work in a section and how much is able to complete the work. (c) Timeliness of work in completing tasks, employees are not only required to quickly complete their work but also must be right or in accordance with the expectations of superiors. (d) Attendance with attendance shows the morale of the employee.

\subsection{Data Analysis Method}

\subsubsection{Validity and Reliability Test}

The validity of a measuring instrument shows how far the gauge can measure what should be measured (Cooper \& Schindler 2013). According to Hair et al. (2010), factor loading 0.3 was considered to meet the minimum level, factor loading 0.4 was considered better and in accordance with the rule of thumb used by the researchers, and a factor loading $\geq 0.5$ was considered significant. To test the validity and reliability of structural equation model (SEM) analysis tools using the AMOS program.

Then continued with the reliability test, this test aims to test the consistency of the indicators used in this study. The indicator is said to be reliable if the measuring instrument shows the value of Construct Reliability greater or equal to 0.7 (Imam Ghozali, 2013). The Construct Reliability formula is explained as follows:

$$
\text { Construct Reliability }=\frac{\left(\sum \text { Standard Loading }\right)^{2}}{\left(\sum \text { Standard Loading }\right)^{2}+\left(\sum \varepsilon j\right)}
$$

\subsubsection{Descriptive Analysis}

To describe the respondent's socio-demographic profile, a percentage analysis will be performed using the following formula:

$$
P=\frac{N x}{N} \times 100 \%
$$

Information :

P: Amount of Percentage

$\mathrm{N}_{\mathrm{x}}$ : The frequency of each answer that has been chosen by the respondent

$\mathrm{N}$ : Number of respondents

\subsubsection{Goodness of Fit Test}

This study uses a structural equation model (SEM) analysis tool using the AMOS program. SEM is a collection of statistical techniques that allow the testing of a complex set of relationships simultaneously (Ferdinand, 2002: 6). 
The size of the fit model required by SEM is in the following table:

Table 1. Goodness of Fit

\begin{tabular}{|c|c|}
\hline Criteria & $\begin{array}{l}\text { Recommended } \\
\text { Value }\end{array}$ \\
\hline Chi-square $\left(\chi^{2}\right)$ & $\begin{array}{l}\text { Expected to be } \\
\text { small }\end{array}$ \\
\hline$\chi^{2}$ - significance probability & $\geq 0.05$ \\
\hline Relative $\chi^{2}(\mathrm{CMIN} / \mathrm{DF})$ & $\leq 2.00$ \\
\hline Goodness-of-fit index (GFI) & $\geq 0.90$ \\
\hline Adjusted goodness-of-fit index (AGFI) & $\geq 0.80$ \\
\hline Tucker-Lewis index (TLI) & $\geq 0.90$ \\
\hline Normed fit index (NFI) & $\geq 0.90$ \\
\hline Comparative fit index (CFI) & $\geq 0.90$ \\
\hline Root mean square error of approximation (RMSEA) & $\leq 0.08$ \\
\hline
\end{tabular}

(Source: Hair et.al., 2009)

\subsubsection{Hypothesis Testing}

Hypothesis testing is used to explain the direction of the relationship between independent variables and the dependent variable. This test is done by path analysis (path analysis) of the model that has been made. SEM technique can simultaneously test complex structural models, so that the path analysis results can be seen in one regression analysis. The results of correlations between constructs are measured by looking at the path coefficients and their significance level which are then compared with the research hypothesis. A hypothesis can be accepted or rejected statistically the level of significance can be calculated. Hypothesis testing in this study is done by comparing the value of $\mathrm{P} /$ probability value (probability value or probability value) or the value that indicates the probability of a data to be generalized with $0.05(5 \%)$. If the $\mathrm{P}$ value is less than $0.05(5 \%)$, the hypothesis developed in the study is supported (Santoso, 2015).

\section{Result}

\subsection{Descriptive Analysis}

\subsubsection{Profile of Respondents}

It can be seen from 242 respondents 62 respondents (25.6\%) were male and 180 respondents (74.4\%) were female. This shows that most of the employees at CV. Amigo Mangesti Utomo is a woman. 49 respondents (20.2 percent) aged between $\leq 20$ years, 89 respondents (36.8 percent) aged 21-25 years, 27 respondents (11.2 percent) aged 26-30 years, 17 respondents (7.0 percent) aged 31-35 years, 26 respondents (10.7 percent) aged 36-40 years, 34 respondents (14.0 percent) aged $\geq 41$ years. This shows that most of the employees at CV. Amigo Mangesti Utomo is 21-25 years old. 105 respondents (43.4 percent) have non-permanent status and 137 respondents (56.6 percent) have permanent status. This shows that most of the employees at CV. Amigo Mangesti Utomo is a permanent employee. 240 respondents (99.2 percent) had a high school / vocational education, 1 respondent (4.0 percent) had a diploma education, 1 respondent (4.0 percent) had an undergraduate education. This shows that most of the employees at CV. Amigo Mangesti Utomo has a high school / vocational education. 113 respondents (46.7 percent) had ten years of <5 years, 52 respondents (68.2 percent) had 5-10 years of service, 12 respondents (5.0 percent) had 10-15 years of service, 34 respondents (14.0 percent) had working period 15-20 years, 27 respondents (11.2 percent) have a service life of 20-25 years, 7 respondents (1.7 percent) 
have a service life $>25$ years. This shows that most of the employees at CV. Amigo Mangesti Utomo has a working life of $<5$ years.

\subsection{Validity and Reliability Test}

Table 2:Validity Test Results

\begin{tabular}{|c|c|}
\hline & Estimate \\
\hline $\mathrm{PPO} 1<\mathrm{PPO}$ & .694 \\
\hline $\mathrm{PPO} 2<\mathrm{PPO}$ & .700 \\
\hline $\mathrm{PPO} 3<-\mathrm{PPO}$ & .685 \\
\hline $\mathrm{PPO} 4<\mathrm{PPO}$ & .796 \\
\hline $\mathrm{PPO}<<\mathrm{PPO}$ & .727 \\
\hline $\mathrm{PPO} 6<\mathrm{PPO}$ & .653 \\
\hline $\mathrm{PPO} 7<-\mathrm{PPO}$ & .794 \\
\hline $\mathrm{PKT} 7<\mathrm{PKT}$ & .637 \\
\hline PKT6 <- PKT & .620 \\
\hline PKT5 <- PKT & .717 \\
\hline PKT $\longleftrightarrow$ PKT & .590 \\
\hline PKT $3 \Leftrightarrow$ PKT & .820 \\
\hline PKT2 $<$ PKT & .789 \\
\hline PKT1 $\_$PKT & .563 \\
\hline
\end{tabular}

\begin{tabular}{|c|c|c|c|}
\hline INO9 & $<$ & INO & .858 \\
\hline INOS & $<$ & INO & .830 \\
\hline INO7 & $<$ & INO & .820 \\
\hline INO6 & $<$ & INO & .638 \\
\hline INO5 & $<$ & INO & .503 \\
\hline INO4 & $<$ & INO & .801 \\
\hline INO3 & $<$ & INO & .742 \\
\hline $\mathrm{INO}_{2}$ & $<$ & INO & .564 \\
\hline INO1 & $<$ & INO & .602 \\
\hline KK1 & $<$ & $\mathrm{KK}$ & .835 \\
\hline $\mathrm{KK} 2$ & $<$ & $\mathrm{KK}$ & .834 \\
\hline $\mathrm{KK} 3$ & $<$ & $\mathrm{KK}$ & .724 \\
\hline KK4 & $<$ & $\mathrm{KK}$ & .738 \\
\hline KK5 & $<$ & $\mathrm{KK}$ & .751 \\
\hline KK6 & $<$ & $\mathrm{KK}$ & .703 \\
\hline KK 7 & $<$ & $\mathrm{KK}$ & .346 \\
\hline $\mathrm{K}$ & $<$ & $\mathrm{KK}$ & .596 \\
\hline
\end{tabular}

Source: Data processing results with Amos (2019)

The results of the validity test as shown in table 2 above show that the KK7 indicator has a factor loading value below 0.5 which indicates that these indicators have a weak relationship with the latent variable of Employee Performance so that these indicators must be reduced to be able to continue testing to the next stage and for all indicators on the variables of Transformational Leadership Perception, Organizational Learning Perception, Innovation and Employee Performance have a loading factor value above 0.5 so that the indicators meet convergent validity.

\section{Table 3:Reliability Test Results}

\begin{tabular}{ccc}
\hline No & Latent Variable & Construct Reliability \\
\hline 1. & Transformational Leadership Perceptions & 0.8577 \\
2. & Perception of Organizational Learning & 0.8842 \\
3. & Innovation & 0.9024 \\
4. & Employee performance & 0.8960 \\
\hline
\end{tabular}

Source: Data processing results with Amos (2019)

The reliability test results in table 3 above use the Construct Reliability formula which has been explained previously where the results show that each variable has a CR value above 0.7 , thus it can be said that the latent variables used in the questionnaire are declared reliable or consistent because it meets the construct construct. Thus the model variables in this study meet the convergent validity and reliability construct so that this research can be continued at the next stage. 


\subsection{Research Instrument Testing Results}

\subsubsection{Goodness of Fit}

Table 4. Goodness of Fit Results

\begin{tabular}{cccc}
\hline Goodness Of Fit Index & $\begin{array}{c}\text { Nilai } \\
\text { Kritis }\end{array}$ & Indeks & Keterangan \\
\hline$\chi^{2}-$ Chi-Square & $\begin{array}{c}\text { Expected } \\
\text { to be small }\end{array}$ & 1107.428 & \\
$\chi^{2}-$ Significance & $\geq 0.05$ & 0.000 & Bad \\
probability & $\leq 2.00$ & 1.884 & Good \\
Relative $\chi^{2}$ (CMIN/DF) & $\geq 0.90$ & 0.913 & Good \\
GFI & $\geq 0.80$ & 0.825 & Good \\
AGFI & $\geq 0.90$ & 0.922 & Good \\
TLI & $\geq 0.90$ & 0.942 & Good \\
CFI & $\geq 0.90$ & 0.915 & Good \\
NFI & $\leq 0.08$ & 0.080 & Good \\
RMSEA & &
\end{tabular}

Source: Primary data, Data processing results with Amos (2019)

The $\chi 2$ value was 1107,428 , with a significant level of 0,000 , for the CMIN / DF index value of 1,884 , GFI value of 0.913 , AGFI value of 0.825 , TLI value of 0.922 , CFI value of 0.942 , NFI value of 0.915 , RMSEA value of 0.080 , so the test model can be well received because it produces goodness of fit (good) on almost all the required criteria.

\subsubsection{Causality Relations}

The figure presents a hypothesis testing model that uses SEM (Structural Equation Model) analysis tools.

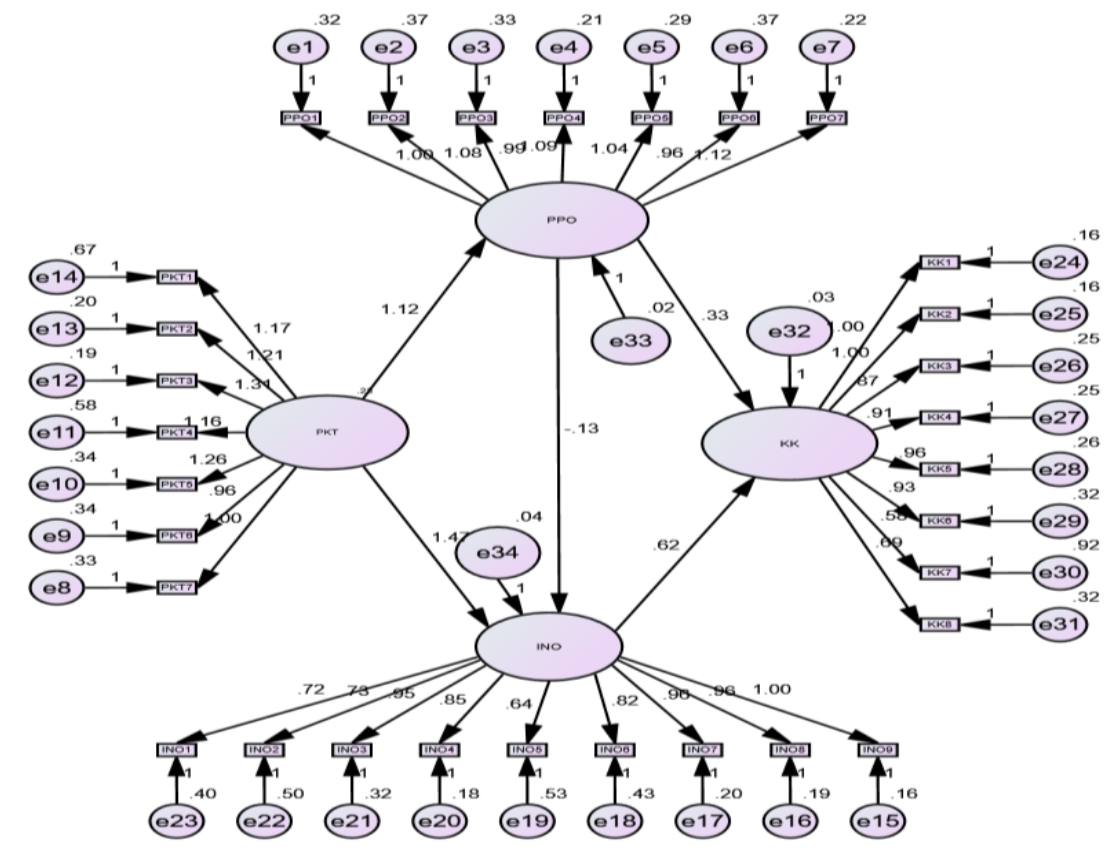

Figure 2

Structural Equation Model 


\subsubsection{Hypothesis Testing}

Table 5: Hypothesis Testing Results

\begin{tabular}{|c|c|c|c|}
\hline Hypothesis & $\mathbf{C R}$ & $\mathbf{F}$ & Information \\
\hline $\begin{array}{l}\text { Transformational Leadership Perception influences } \\
\text { the Perception of Organizational Learning }\end{array}$ & 9,335 & 0.000 & Accepted \\
\hline $\begin{array}{l}\text { Transformational Leadership Perception influences } \\
\text { Innovation }\end{array}$ & 2,181 & 0,029 & Accepted \\
\hline $\begin{array}{c}\text { Perception of Organizational Learning influences } \\
\text { Innovation }\end{array}$ & $0, \overline{2} 28$ & 0,820 & Rejected \\
\hline $\begin{array}{l}\text { Perception of Organizational Learning affects } \\
\text { employee performance }\end{array}$ & 2,41 & 0,016 & Accepted \\
\hline Innovation affects employee performance & 5,105 & 0.000 & Accepted \\
\hline
\end{tabular}

The test results show that the transformational leadership perception variable has a positive and significant effect on organizational learning perceptions, this is supported by the results of hypothesis testing which shows a significance value of 0,000 . These results indicate that Hypothesis 1 which states that the perception of transformational leadership influences the perception of organizational learning is accepted and has a strong causality relationship as seen from the C.R value of 9.335 .

The test results show that the transformational leadership perception variable has a positive and significant effect on innovation, this is supported by the results of hypothesis testing which shows a significance level of 0.029 . These results indicate that Hypothesis 2 which states that transformational leadership perceptions influence innovation is accepted and has a strong causality relationship as seen from the C.R value of 2.181 .

Testing the influence of organizational learning perception variables show results that have no significant effect on innovation, This is supported by the results of hypothesis testing which shows a significance number of 0.820 . These results indicate that Hypothesis 3 which states that organizational learning perceptions influence innovation is rejected and has a very weak causality relationship as seen from a C.R value of -0.278 .

The test results show that the variable perception of organizational learning has a positive and significant effect on employee performance, this is supported by the results of hypothesis testing which shows a significance level of 0.016. These results indicate that Hypothesis 4 which states that organizational learning perceptions influence employee performance is accepted and has a strong causality relationship as seen from a C.R value of 2,410 .

The test results show that the innovation variable has a positive and significant effect on employee performance, this is supported by the results of hypothesis testing which shows a significance value of 0,000 . These results indicate that Hypothesis 5 which states innovation affects employee performance is accepted and has a strong causality relationship as seen from the C.R value of 5.105. 


\subsubsection{Discussion}

\section{Influence of Transformational Leadership Perceptions on Organizational Learning Perceptions.}

Based on the results of data analysis on transformational leadership perceptions of organizational learning perceptions on the CV. Amigo Mangesti Utomo, showed that the perception of transformational leadership had a positive and significant influence on the perception of organizational learning. This shows that every leader who provides organizational learning for his employees automatically in the company will have a good impact for the company, especially for employees of CV. Amigo Mangesti Utomo

\section{Influence of Transformational Leadership Perceptions on Innovation}

Based on the results of data analysis on transformational leadership perceptions of innovation in the CV. Amigo Mangesti Utomo, showed that the perception of transformational leadership had a positive and significant influence on innovation. Managers' perceptions of their role in their organization greatly influence the ability to promote such leadership in an organization. These results give meaning that having a good leader and supporting all employee activities can help an employee to work better in order to create innovations or new ideas needed by the CV. Amigo Mangesti Utomo.

\section{Effects of Organizational Learning Perceptions on Innovation}

Based on the results of data analysis of organizational learning perceptions of innovation in the $\mathrm{CV}$. Amigo Mangesti Utomo, shows that organizational learning perceptions influence positively but not significantly to innovation. The results of this study give meaning that learning is one of the factors that supports the CV. Amigo Mangesti Utomo can develop even better although in its implementation still found obstacles, for example the limitations of human resources and information technology. The link why organizational learning is not significant to innovation can occur because the level of employee education turns out to be only high school / vocational high school graduates so that knowledge is sufficiently lacking while organizational learning is better applied at managerial level.

\section{The Effect of Organizational Learning Perceptions on Employee Performance}

Based on the results of data analysis of organizational learning perceptions of employee performance on the CV. Amigo Mangesti Utomo, showed that the perception of organizational learning had a positive and significant effect on employee performance. The results of this analysis mean that employees have positive thoughts to develop or advance, where this will have an impact on the achievement of employee performance and organizational learning that has an effect on all employees due to the different levels of knowledge.

\section{Effect of Innovation on Employee Performance.}

Based on the results of the analysis of innovation data on employee performance in the CV. Amigo Mangesti Utomo, showed that innovation affects positively and significantly on employee performance. This shows that the more creation of ideas, ideas and new innovations, it shows that the increase in employee performance CV. Amigo Mangesti Utomo. 


\section{Conclusions and Suggestions}

This research was conducted by collecting data through surveys of employees of CV. Amigo Mangesti Utomo. The general research objective is to look at the impact of transformational leadership perceptions on employee performance through the perception of organizational learning and innovation. The results showed that; (a) The perception of transformational leadership has an important impact on the perception of organizational learning in the CV. Amigo Mangesti Utomo. The better transformational leadership shown will encourage organizational learning practices in the $\mathrm{CV}$ environment. Amigo Mangesti Utomo. (b) Perception of transformational leadership has an important impact on innovations carried out in the CV. Amigo Mangesti Utomo. The more transformational leadership is applied, the tendency for innovation can be created. (c) Perception Organizational learning cannot have an important impact on innovation on the CV. Amigo Mangesti Utomo. More often organizational learning is given to employees of CV. Amigo Mangesti Utomo then tends not to give influence to the creation of new innovations in CV. Amigo Mangesti Utomo. (d) The perception of organizational learning has an important impact on employee performance in the CV. Amigo Mangesti Utomo. The better organizational learning practices that are applied in the CV environment. Amigo Mangesti Utomo then can give meaning to employee performance on the CV. Amigo Mangesti Utomo. (e) Innovation that is more reflected in the drive to find new ways for the organization can play an important role in the performance of employees in the CV. Amigo Mangesti Utomo. The more creation and positive practice of innovation applies, it will encourage the achievement of employee performance so as to advance the CV. Amigo Mangesti Utomo. Future research directions include; research not only in the CV. Amigo Mangesti Utomo, further research with more research objects, further research to develop research objects in other types of industries such as insurance, banking, IT, manufacturing, etc., to overcome the common method bias can be done by considering the time lag (longitudinal) of each statement. For example, filling out the statement about Transformational Leadership Perception in the first week of the survey, about Organizational Learning Perception in the second week of the survey, about Innovation in the third week of the survey, about Employee Performance in the fourth week of the survey, the practical implication is that this research is expected to be used as a development tool human resources at CV Amigo Mangeti Utomo.

\section{Refrences}

Adair, J. (1990). The challenge of innovation. England: The Talbot Adair Press.

Ali, N., Vahid, M. D., Behnaz, A., Salman, N. S., \& Aliasghar, R. (2012). Relations between transformational leadership, organizational learning, knowledge management, organizational innovation, and organizational performance: an empirical investigation of manufacturing firms. International Journal of Advanced Manuf acturing Technology, 64:1073-1085.

Amabile, T. M. (1996). Assesing The Work Environment For Creativity. Academy of Management Journal, 1154-1184.

Argyris, C., \& Schon, D. A. (1978). Organizational Learning : Theory of Action Perspsctive. AddisonWesley: Reading MA.

Argyris, C., \& Schön, D. A. (1996). Organizational learning II: theory, method, and practice. London: Addison-Wesley. 
Bass, B. M., \& Avolio, B. J. (1994). Improving Organizational Effectiveness through Transformational Leadership. California: Sage Publications.

Bass, B. M., \& Avolio, B. J. (2000). MLQ multifactor leadership questionnaire technical report. Thousand Oaks: Sage Publications.

Bastian, I. (2001). Akuntansi Sektor Publik di Indonesia. Yogyakarta: BPFE.

Bernardin, H. J., \& Russel. (2010). Human Resource Management. New York: McGraw-Hill.

Bueno, E., Aragón, J. A., Salmador, M. P., \& García, V. J. (2010). Tangible slack versus intangible resources: the influence of technology slack and tacit knowledge on the capability of organizational learning to generate innovation and performance. International Journal of Technology Management, 49(4):314-37.

Byars, \& Rue. (1981). Strategic Management Planning and Implementation. New York: Harper and Row Publisher.

Calantone, R. J., Cavusgil, T. S., \& Zhao, Y. (2002). Learning orientation, firm innovation capability, and firm performance. Industrial Marketing Management, 31:515-24.

Capron, L. (1999). The long-term performance of horizontal acquisitions. Strategic Management Journal, 20:987-1018.

Cece, W. (1992). Kemampuan Guru Dalam Proses Belajar Mengajar. Bandung: PT Remaja Rosda Karya.

Coad, A. F., \& Berry, A. J. (1998). Transformational leadership and learning orientation. Leadership and Organization Development Journal, 19(3):164-72.

Cohen, W. M., \& Levinthal, D. A. (1990). Absorptive capacity: a new perspective on learning and innovation. Administrative Science Quarterly, 35:128-52.

Cohen, W. M., \& Levinthal, D. A. (1990). Absorptive capacity: a new perspective on learning and innovation. Administrative Science Quarterly, 35:128-52.

Colbert, A. E., Kristof-Broiatn, A. L., Bradley, B. H., \& Barrick, M. R. (2008). CEO transformational leadership: the role of goal importance congruence in top management teams. Academy of Management Journal, 51(1):81-96.

Conger, A. J. (1999). Charismatic and transformational leadership in organizations: an insider's perspective on these developing streams of research. The Leadership Quarterly, 10(2):145-79.

Cooper, D. R., \& Schindler, P. S. (2013). Business research methods. 12th Ed. New York: McGraw-Hill.

Damanpour, F. (1991). Organizational innovation: a meta-analysis of effects of determinants and moderators. Academy of Management Journal, 34:555-90.

Danneels, E., \& Kleinschmidt, E. J. (2001). Product innovativeness from the firm's perspective: its dimensions and their relation with project selection and performance. The Journal of Product Innovation Management, 18:357-73. 
Decarolis, D. M., \& Deeds, D. L. (1999). The impact of stocks and flows of organizational knowledge on firm performance: an empirical investigation of the biotechnology industry. Strategic Management Journal, 20:953-68.

Dibella, A., Navis, E., \& Gould, J. (1996). Understanding organizational learning capability. Journal of Management Studies, 33:361-79.

Donaldson, L. (2001). The Contingency Theory of Organizations. Thousand Oaks, CA: Sage Publications.

Edin, S., Milan, N., \& Senad, S. (2017). Impact Of Transformational Leadership On Business Performance. Technical Gazette 24, Suppl, 435-444.

Ferdinand, A. (2002). Structural Equation Modeling dalam Penelitian Manajemen, Edisiketiga. Semarang: Fakultas Ekonomi UNDIP.

Fiol, C. M., \& Lyles, M. A. (1985). Organizational learning. Academy of Management Review, 10:80313.

Forrester, R. H. (2000). Capturing learning and applying knowledge: an investigation of the use of innovation teams in Japanese and American automotive firms. Journal of Business Research, $47: 35-45$.

Garcia, M. V., Llorens, M. F., \& Verdu, J. A. (2006). Antecedents and consequences of organizational innovation and organizational learning in entrepreneurship. Industrial Management \& Data Systems, 106(1-2):21-42.

Garcia, M. V., Llorens, M. F., \& Verdu, J. A. (2008). The effects of transformational leadership on organizational performance through knowledge and innovation. British Journal of Management, a;19(4):299-319.

García-Morales, V. J. (2004). Aprendizaje Organizacional: Delimitacióny Determinantes Estratégicos. Granada: Universidad de Granada.

Garvin, D. A. (2000). Learning in Action: A Guide to Putting the Learning Organization to Work. Boston, Messachusettes: Harvard Business School Press.

Geenberg, J., \& Baron, R. A. (2000). Behavior in Organization . Newjersey: Prentice-Hall.

Ghozali, I. (2002). Aplikasi Analisis Multivariat dengan Program SPSS. Semarang: Badan Penerbit Universitas Diponegoro.

Gibson, J. L. (2003). Struktur Organisasi dan Manajemen. Jakarta: Erlangga 5.

Glynn, M. A. (1996). Innovative genius: a framework for relating individual and organizational intelligences to innovation. Academy of Management Review, 21:1081-111.

Gopalakrishnan, S. (2000). Unraveling the links between dimensions of innovation and organizational performance. The Journal of High Technology Management Research, 11(1):137-53. 
Gowen, C., Henagan, S., \& McFadden, K. (2009). Knowledge management as a mediator for the efficacy of transformational leadership and quality management initiatives in US health care. Health Care Management Review, 34(2):129-40.

Gumusluoglu, L., \& Ilsev, A. (2009). Transformational leadership, creativity, and organizational innovation. Journal of Business Research, 62(4):461-73.

Guns, B. (1996). The Faster Learning Organization; Gain and Sustain the Competitive Edge. Pfeiffer and Company.

Hair, J. F., Anderson, R. E., Tatham, R. L., \& Black, W. C. (2010). Multivariate Data Analysis. 7th Ed. Ney Jersey: Prentice-Hall International.

Hair, R. F., Anderson, R. E., Tatham, R. L., \& Black, W. C. (2009). Multivariate Data Analysis. Edisi 9. New Jersey: Pearson.

Hall, I. A., \& Bagchi-Sen, S. (2000). A study of R\&D, innovation, and business performance in the Canadian biotechnology industry. Technovation, 22:231-44.

Hoopes, D. G., \& Postrel, S. (1999). Shared knowledge, 'glitches', and product development performance. Strategic Management Journal, 20:837-65.

Hudges, M., \& Morgan, R. R. (2007). Deconstructing the relationship between entrepreneurial orientation and business performance at the embryonic stage of firm growth. Industrial Marketing Management, 36:651-61.

Hurley, R. F., \& Hult, G. T. (1998). Innovation, market orientation, and organizational learning: an integration and empirical examination. Journal of Marketing 1998;62:42-54, 62:42-54.

Hurley, R. F., \& Hult, G. T. (1998). Innovation, market orientation, and organizational learning: an integration and empirical examination. Journal of Marketing, 62:42-54.

Ilyas, Y. (1999). Kinerja: Teori Penilaian dan Penelitian. Jakarta: PT Gramedia Pustaka Utama.

Inkpen, A. C., \& Crossan, M. M. (1995). Believing is seeing: joint ventures and organizational learning. Journal of Management Studies, 32:595-618.

Irawan, H. (2002). 10 Prinsip Kepuasan Pelanggan. Jakarta: PT Elex Media Komputindo.

Ireland, R. D., Hitt, M. A., Camp, S. M., \& Sexton, D. L. (2001). Integrating entrepreneurship actions and strategic management actions to create firm wealth. Academy of Management Executive, 15(1):49-63.

Irwin, J. G., Hoffman, J. J., \& Lamont, B. T. (1998). The effect of the acquisition of technological innovations on organizational performance: a resource-based view. Journal of Engineering and Technology Management, 15:25-54.

Kanter, R. M. (1983). The change masters. New York: Simon \& Schuster.

Kotler, P., \& Gary, A. (2013). Dasar-Dasar Pemasaran. Jakarta: Prenhalindo. 
Lefebvre, E., \& Lefebvre, L. A. (1992). Firm innovativeness and CEO characteristics in small manufacturing firms. Journal of Engineering and Technology Management, 9:243-77.

Lei, D., Slocum, J. W., \& Pitts, R. A. (1999). Designing organizations for competitive advantage: the power of unlearning and learning. Organizational Dynamics, 28(3):24-38.

Lengnick-Hall, C. A. (1992). Innovation and competitive advantage: what we know and what we need to learn. Journal of Management, 18:399-429.

Lian, S. S. (2006). Across-cultural test of the 'five-factor model of personality and Across-cultural test of the 'five-factor model of personality and transformational leadership. Journal of Business Research, 59(8):936-44.

Lieberman, M., \& Montgomery, D. (1988). First mover advantages. Strategic Management Journal, 9:41-58.

Lööf, H., \& Heshmati, A. (2002). Knowledge capital and performance heterogeneity: a firm-level innovation study. International Journal of Production Economics, 76:61-85.

Lu, C., Wei, Z., Baiyin, Y., \& Shuaijiao, B. (2016). Transformational leadership, social capital and organizational innovation. Leadership \& Organization Development Journal, 843-859.

Luthans, F. (1995). Organizational Behavior. Singapore: Mc Graw - Hill.

Maani, K., \& Benton, C. (1999). Rapid team learning: lessons from team New Zealand America's Cup campaign . Organizational Dynamics, 28(4):48-62.

Manz, C., Barstein, D. T., Hostager, T. J., \& Shapiro, G. L. (1989). Leadership and innovation: a longitudinal process view. New York: Harper and Row.

Mathis, \& Jackson. (2009). Manajemen Sumber Daya Manusia. Jakarta: Salemba Empat.

Mathis, L. R., \& Jackson, H. J. (2001). Manajemen Sumber Daya Manusia. Jakarta: Buku kedua. McDonough, E. F. (2000). Investigation on factors contributing to the success of cross-functional teams. Journal of Product Innovation Management, 17:221-35.

McGill, M. E., Slocum, J. W., \& Lei, D. (1992). Management practices in learning organizations. Organizational Dynamics, 21(1):5-17.

Meeus, M. T., \& Oerlemans, L. A. (2001). Patterns of interactive learning in a high-tech region. Organization Studies, 22:145-72.

Menguc, B., Auh, S., \& Shih, E. (2007). Transformational leadership and market orientation: implications for the implementation of competitive strategies and business unit performance. Journal of Business Research, 60(4):314-21.

Mezias, S. I., \& Glynn, M. A. (1993). The three faces of corporate renewal: Institution, revolution, and evolution. Strategic Management Journal, 14:77-101.

Munir. (2008). Kurikulum Berbasis Teknologi Informasi dan Komunikasi. Bandung: Alfabeta. 
Nonaka, I., \& Takeuchi, H. (1995). The knowledge-creating company: how Japanese companies create the dynamics of innovation. New York: Oxford University Press.

Ogbonna, E., \& Harris, L. C. (2000). Leadership style, organizational culture and performance: empirical evidence from UK companies. International Journal of Human Resource Management, 11(4):766-88.

Parmono. (2001). Pengembangan Sumber Daya Manusia dalam Era Globalisasi. Jakarta: PT Grasindo.

Pedler, M. (1991). Action Learning in Practise. UK: Henley Business School.

Robbins, S. P. (1996). Perilaku Organisasi. Jakarta: Prenhalindo.

Sánchez, R., \& Mahoney, J. T. (1996). Modularity, flexibility, and knowledge management in product and organization design. Strategic Management Journal, 17:63-76.

Sangkala. (2007). Knowledge Management: Suatu pengantar Memahami Bagaiamana Organisasi Mengelola Pengetahuan Sehingga Menjadi Organisasi yang Unggul . Jakarta: Rajawali Press.

Santoso, S. (2015). Menguasai Statistik Multivariat. Jakarta: PT Elex Media Komputindo.

Schein, E. H. (1993). On dialogue, culture, and organizational learning. Organizational Dynamics, 22(2):40-51.

Scott, S. C., \& Bruce, R. A. (1994). Determinants of innovative behavior: a path model of individual innovation in the workplace. Academy of Management Journal, 37:580-607.

Senge, P. M. (1990). The fifth discipline. New York: Doubleday Publ.

Senge, P., Roberts, C., Ross, R. B., Smith, B. J., \& Kleiner, A. (1994). The fifth discipline fieldbook. New York: Doubleday Publ.

Simonaitien, M. B. (2007). Besimokancios Organizacijos Vystymas: Mokslo Studija (School - a learning organizatio n deve lopmentScience study. Kaunas: Technologija.

Slater, S. F., \& Narver, J. C. (1995). Market orientation and the learning organization. Journal of Marketing, 59(3):63-74.

Snyder, W. M., \& Cummings, T. G. (1998). Organization learning disorders: conceptual model and intervention hypotheses. Human Relations, 51:873-95.

Suharto, B. (2005). Pengaruh Kepemimpinan Transaksional dan Transformasional terhadap Kepuasan dan Kinerja Bawahan pada Sekolah Tinggi Agama Islam Negeri di Jawa Timur. Jurnal Ekonomi \& Bisnis.

Tierney, P., Farmer, S. M., \& Graen, G. B. (1999). An examination of leadership and employee creativity: the relevance of traits and relationships. Personnel Psychology, 52:591-620.

Tjakraatmadja, \& Lantu. (2006). Knowledge Management dalam Konteks Organisasi Pembelajar. Bandung: Sekolah Bisnis dan Manajemen (SBM) Institut Teknologi Bandung. 
Tsang, E. W. (1997). Organizational learning and the learning organization: a dichotomy between descriptive and prescriptive research. Human Relations, 50:73-89.

Tushman, M. L., \& Nadler, D. A. (1986). Organizing for innovatio. California Management Review, 28(3):74-92.

Van de Ven, A. H. (1986). Central problems in the management of innovation. Management Science, 32:590-607.

Victor, J. G.-M., Fransisco, J. L.-M., \& Antonio, J. V.-J. (2008). The Effects of Transformational Leadership on Organizational Performance through Knowledge and Innovation. British Journal of Management, 19, 299-319.

Watkins, K., \& Marsick, V. (1996). In action: Creating a learning organization. Alexandria: American Society for Training and Development.

Wick, C. W., \& Leon, L. S. (1995). From ideas to action: creating a learning organization. Human Resource Management, 34:299-311.

Yli-Renko, H., Autio, E., \& Sapienza, H. J. (2001). Social capital, knowledge acquisition, and knowledge exploitation in young technology-based firms. Strategic Management Journal, 22:587-613.

Zahra, S. A., Ireland, R. D., \& Hitt, M. A. (2000). International expansion by New Venture firms: international diversity, mode of market entry, technological learning, and performance. Academy of Management Journal, 43:925-50.

Zaltman, G., Duncan, R., \& Holbeck, J. (1973). Innovations and organizations. New York: Wiley.

Zaltman, G., Duncan, R., \& Holbeck, J. (1973). Innovations and organizations. New York: Wiley .

Zhu, W. C., Chew, I. K., \& Spangler, W. D. (2005). CEO transformational leadership and organizational outcomes: the mediating role of human-capital-enhancing human resource. Leadership Quarterly, 16(1):39-52.

\section{Copyrights}

Copyright for this article is retained by the author(s), with first publication rights granted to the journal.

This is an open-access article distributed under the terms and conditions of the Creative Commons Attribution license (http://creativecommons.org/licenses/by/4.0/). 